\title{
Educaţia teologică între expresia duhovnicească și constrângerile seculare ale contemporaneității
}

Ovidiu PANAITE*

\begin{abstract}
Theological education between liturgical expression and contemporary pedagogical rigors. This study aims to highlight the internal elements of religious education. The Sacred and the sacred play a very important role in the religious educational system. The image of the sacred is revealed in a clearer way in the New Testament in Christ: Who is greater than the temple. Another chapter is dedicated to cultural beliefs such as those imagined by Grace Davie for Great Britain: believing without belonging. The historical sequence has the role of identifying possible Christian educational models in the first fathers of the Church. The last chapter is dedicated to the theological tasks that are imposed in
\end{abstract} the context of secular pressures.

Keywords: theological education, cultural beliefs, secular pressures.

\section{Prolegomena}

Unul dintre marii părinţi care a rămas în conştiinţa dogmatică a Bisericii cu numele de teolog practic, anume Evagrie Ponticul, pune un foarte mare accent pe stăpânirea gândurilor şi nerisipirea minţii cu ajutorul rugăciunii: ,dacă nu te poţi linişti uşor în părţile tale adânci, grăbeşte spre înstrăinarea cu voia şi întăreşte-ţi gândul spre ea......te sfătuiesc iarăşi: iubeşte înstrăinarea, căci te izbăveşte de împrejurările ţinutului tău şi te

* Pr. conf. univ. dr., Facultatea de Teologie Ortodoxă, Universitatea „1 Decembrie 1918" Alba Iulia. 
face să te bucuri numai de folosul minţii”. Consider că această atitudine a lui Evagrie sintetizează esenţa liturgică a educaţiei, punând în circulaţie adevăruri valabile atât pentru cei care îmbrăţişează viaţa monahală, cât şi pentru cei care au luat asupra lor harisma aceasta de a dăltui caractere, de a forma, de a educa. Quintesenţa educaţiei stă aşadar în trezvie, ca atitudine de angajare şi disponibilitate de descoperire. Un cercetăror spunea la un moment dat că renunţarea la a ucenici pe lângă marile adevăruri este echivalentul unei morţi premature.

\section{În căutarea Sacrului}

Reflexia biblică este orientată spre definirea lumii în general, deci implicit a educaţiei, în relaţie directă cu dimensiunea sacrului. În secolul trecut conceptul de sacru devine cuvântul cheie pentru ştiinţa empirică a religiilor. Ilustrativ în acest sens este grupul de cercetători cu contribuţii asupra fenomenologiei religiei: R. Otto, G. Van der Leew, N. Söderblom, M. Eliade. Rudolf Otto în celebra lucrare Das Heliege, propune sacrul ca şi categorie fundamentală a religiei. Pe parcursul lucrării demonstrează existenţa a doi poli coordonaţi între ei de experienţa religioasă: tremendum şi fascinans. Omul este fascinat în viziunea lui G. Van der Leew de puterea sacră. Această putere sacră este la o mare depărtare de om şi în acelaşi timp înfricoşătoare. Antiteza sacru-profan a făcut şi obiectul cercetărilor lui Eliade. Sensul termenului de profanum în accepţiunea lui Eliade este acela prin care indică o categorie umană care stă în afara templului, o categorie care nu are caracter negativ, ci neutru. Ideea este că totul şi toate au posibilitatea de a deveni sacre: spaţiul, timpul, cerul, pământul ${ }^{1}$. Locul sacru este prin excelenţă templul al cărui adyton ascundea imaginea zeilor, unde nu se putea intra pentru că era o continuă teofanie. La puţin timp după publicarea cărţii lui Rudolf

${ }^{1}$ Wilhelm Dancă, Mircea Eliade. Definitio Sacri, Iaşi, Edit. Ars Longa, 1998, p. 199; Nicolae MorAR, Dumnezeu-comuniune de persoane, paradigmă a comuniunii umane, în vol. Orizontul sacru..., p. 158. 
Otto despre sacru a apărut comentariul lui Karl Barth la Epistola către Romani a Sfântului Apostol Pavel. Religia vine definită în

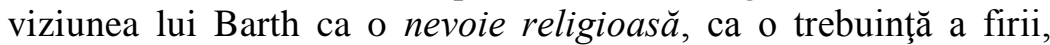
după cum este trebuinţa de mâncare sau de somn. Religia este o parte a omului, este numai din om. Pe această cale omul nu poate să ajungă niciodată la Dumnezeu, lucrul acesta fiind posibil numai prin harul care vine de sus. Într-un asemenea mod Barth se depărta de teologia evanghelică a secolului XIX, se depărta şi de Schleiermacher care definise religia ca fiind sentimentul absolutei dependenţe a protestantismului cultural ${ }^{2}$. Mărul discordiei fusese aruncat. Ştiinţele biblice vor face mari eforturi de a soluţiona problema. Biblic va fi demonstrat faptul că sacralitatea obiectivă ocupă un loc important în Vechiul Testament. Iubirii lui Dumnezeu, Israel îi răspunde cu un cult care este expresia unei raportări personale la divinitate. Religiozitatea templului poartă în sine caracterul cultului, adică sacrul.

Mentalul ebraic vechitestamentar dezvoltă o semnificaţie a sacrului în termenii rezultatului unui proces de separaţie la care se va asocia ideea de puritate, curăţie, transcendenţă. Echivalentul ebraic al termenului de sfânt (qüdôš; qôdě̌ $=$ sfinţenie) este o derivaţie de la rădăcina qd [a separa, a (se) pune deoparte] aflat într-o strânsă legătură filologică cu termenul quddusu (pur, curat, minunat, splendid). Determinarea semanticii teologice a lui qüdôs se află într-o relaţie mai apropiată cu rădăcina $q d$ ca şi separaţia de ceea ce este profanum decât cu quddusu. Acest sens vine sugerat de I Samuel 21,5 şi Iezechiel 22, 26 fragmente în care qädôš se defineşte în opoziţie cu $\hat{h} \bar{o} l$ (profan). Aceeaşi concluzie se impune

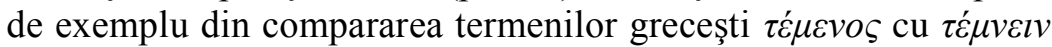
sau a latinului sanctus cu sancire. Isaia în 6,3 foloseşte în numirea lui Dumnezeu termenul qädôś, utilizat în sensul de a numi transcendenţa Lui şi în aceeaşi paletă de sinonimie, dar pentru a indica unicitatea relaţiei lui Dumnezeu cu populus ellectum, expresia Sfântul lui Israel [apare cu cea mai mare

${ }^{2}$ Die Heissen Eisen von A bis Z, Johannes BAUER, Graz, Austria, Verlag, trad. it. Dizionario Teologico, Roma, Cittadela Editrice, 1974, p. 667. 
frecvenţă la Isaia şi foarte puţin în alte locuri din Biblie (II Regi, Ieremia şi în Psalmi)] $]^{3}$. Septuaginta traduce de cele mai multe ori termenul qädôs cu $\alpha \dot{\gamma} ı o \varsigma$, un termen cu utilizare rară în greaca clasică ${ }^{4}$, în timp ce Noul Testament dezvoltă cu consecvenţă filologia lui $\dot{\alpha} \gamma l o \varsigma$. Din această scurtă introducere reiese că termenul biblic de sfânt are sub aspect etimologic şi semantic semnificaţia de separat, pus deoparte.

Pe de altă parte întâlnim principii care proiectează sacrul într-o existenţă îndepărtată. Motivul este acela de a proteja poporul ales de pericolul reprezentărilor figurative şi în acest sens de riscul idolatriei. Imaginea sacrului se descoperă într-o manieră mai clară în Noul Testament în Hristos: Care este Unul mai mare decât templul. Yves Congar concluzionează cu aceste cuvinte conceptul noutestamentar de sacru: Hristos a adus în propria persoană anticul privilegiu al Templului, adică privilegiul de a fi locul în care se poate găsi prezenţa şi mântuirea lui Dumnezeu, punctul de pornire din care pleacă orice sfinţenie. Noul Testament nu cunoaşte un sacrificiu cultual în sensul antic al cuvântului. Conform lui H. Schurmann se intră într-o perioadă eshatologică, în care activităţile sacrale şi cultuale vor fi repudiate. Sub influenţa criticii religiei din partea lui Karl Barth, precum şi sub influenţa rezultatelor ştiinţelor biblice, se construieşte noua viziune a timpului odată $\mathrm{cu}$ declinul religiozităţii. Paradigma este pusă în evidenţă de scrisorile lui Bonhoeffer din 1943 şi 1944, alcătuite în închisoare, şi publicate în volumul Widerstand und Ergebung ${ }^{5}$. Bonhoeffer este convins că drumul pe care se merge este către o epocă închisă religiei. Pune în circulaţie sintagma de creştinism areligios prin care înţelege că termenul de religie nu este corelativ cu cel de creştinism, modificând fundamental conţinutul credinţei. În consecinţă Hristos nu mai este obiectul religiei, ci ceva foarte

3 ***, Introduction a Ésaïe, în La Bible, traduction œecuménique TOB, Société Biblique Française, Les Éditions du Cerf, 1994, p. 752.

${ }^{4}$ Septuaginta, edit. Alfred RAHLFS, Stuttgart, Deutsche Bibelgesellschaft, 1979, p. 567-573.

${ }^{5}$ Die Heissen Eisen von A bis Z..., p. 669. 
divers. În această optică apare ipoteza procesului de secularizare. Max Weber descrie faptul ca o descreştinare şi demitizare progresivă a lumii, atenuând importanţa religiei, organizată ca instrument de control social. Weber demonstrează că lumea protestantă a avut un rol esenţial în această direcţie. Teologul evanghelic F. Gogarten reia acest tip de demonstraţie în volumul său din 1953 Verhängnis und Hoffnung der Neuzeit în care arată că secularizarea ar fi o consecinţă legitimă şi necesară credinţei creştine. Libertatea creştinului stă în posibilitatea de a dispune de întreaga lume într-o manieră în care nu există constrângere. Pericolul apare în secularismul care neagă libertatea spirituală şi religioasă, încorsetând totalmente omul şi negând credința. $\mathrm{O}$ altă voce care nuanţează problema este aceea a lui Paul Tilich. Nerenunţând la ambivalenţa religiei, Tilich susţine că sacrul nu este departe de lumea creată, ci este aproape. Pe de altă parte Dumnezeu este distinct de orice creatură, deci proiectat într-o metafizică specifică $\breve{b}^{6}$. Experienţa istorică a demonstrat falsitatea predicţiei lui Bonhoeffer. Noile mişcări religioase, reîntoarcerea sacrului, au modificat paradigmele din 1943-1944.

Începând cu Conciliul II Vatican secularizarea a trecut în rândul dezbaterilor teologilor catolici. Y. Congar, J.B. Metz, H. Schürmann, E.J. Lengeling, M.D. Chenu pornind de la premise diverse şi-au asumat poziţii teoretice interesante. H. Mühlen încearcă o clarificare a problemei în studiul cu titlul Entsakralisierung. Printre diferenţierile care le aduce ca argumente pentru ambivalenţa interpretării, Mühlen face distincţia între sfânt şi sacru, după cum filosofia face diferenţiere ontologică între esenţă şi existenţă, sau teologia între Dumnezeu şi creatură. În viziunea lui secularizarea, în varianta ei pozitivă, înseamnă relativizarea tuturor absolutizărilor care vin din lumea transcendentă, în timp ce semnificaţia ei negativă stă în pericolul continuu de a nega orice referire la Dumnezeu din partea mundanului. O astfel de teorie a fundamentat absolutismele statale moderne.

6 Dizionario Enciclopedico di Teologia Morale, diretto da Leandro Rossi e Ambrogio VALSECHI, Roma, Edit. Paoline, 1974, p. 973. 


\section{Logica modernă a credinței culturale și recompunerea Sacrului}

Religiozitatea modernă pusă sub semnul individualismului cunoaşte o largă răspândire în Europa. Cazul francez demonstrează orientarea acestui tip de individualism spre comunităţi emoţionale sau spre o nouă laicitate. Într-o asemenea perspectivă Dumnezeu nu mai este conceput ca persoană ci numai ca o forţă superioară şi impersonală, adeziunea la creştinism fiind acceptarea unui cod care ar conţine o seamă de valori morale ${ }^{7}$. Similar este cazul Belgiei unde asistăm la o recompunere a credinţei, pornind de la aceleaşi date ale individualismului, scepticismului şi relativizării. Studiile de sociologie a religiilor au demonstrat existenţa unor combinaţii între practicile tradiţionale de credinţă şi diverse mişcări mistico-ezoterice în care actul decizional stă la periferia libertăţii individului, obligându-l la numeroase opţiuni. Toate construiesc sisteme colective de semnificaţii care mai târziu se manifestă în mod autonom, dând naştere unor credinţe culturale de tipul celei imaginate de Grace Davie pentru Marea Britanie: believing without belonging ${ }^{8}$. Autonomizarea creează un climat favorabil proliferării microgrupurilorsau a microcomunităţilor bazate pe sisteme de interese sociale, culturale sau spirituale. În spatele unor astfel de opţiuni se întâlneşte caracterul modernităţii culturale care nu acceptă grupuri de tip-Biserică, libertatea individului manifestându-se în această spiritualitate de tip sectă. Această insistenţă pe dimensiunea protestatară antimodernă urmăreşte un

${ }^{7}$ E. Hamberg, Religion, Secularisation and value Change in the Welfare State, comunicare la prima Conferinţă Europeană de Sociologie, Viena, august, 1992, apud Daniele Hervieu LEGER, Credere nell ambito della modernita: aspetti del fatto religioso contemporaneo in Europa,în Encyclopedie des religions $V$, cord de F. LenOIR et Y.T. MASQuelier, Paris, Baxard Editions, 1997, trad. it. La religione $V$, Torino, Unione Tipografico-Editrice Torinese, 2001, p. 533.

${ }^{8}$ G. DAVIE, "Believing without belonging: is it the future of religion in Great Britain?”, in Social Compass, 37, 1990, 4, apud Ibidem, p. 536. 
paralelism determinat de apariţia şi evoluţia noilor comunităţi religioase în Europa şi criza economică, socială şi culturală din preajma anului 1970. Toate aceste practici se înscriu într-o logică modernă şi raţională a lui do ut des, în mod sigur orientată spre wertrationalität (raţionalitate orientată spre o valoare), decât spre zweckrationalität (raţionalitate orientată spre final). În fapt omenirea are nevoie de supranatural, este o necesitate ontologică a împlinirii, sesizată de părinţii Bisericii (Fericitul Augustin: inquietum est meum core... donec requiescat in Te) dar şi de antropologi sau alţi cercetători (conceptul de hommo religiosus).

În variantă contemporană două sunt tendinţele de autodivinizare; una gnostică (credinţele oriental-tibetane, şamanismul, mahikari sau nichiren shoshu, tantra, yoga etc.) şi alta umanistă (meditaţia transcendentală, psihanaliza etc.). Autonomizarea şi societatea de consum au alimentat miturile modernităţii culturale şi au diversificat ideologic tipurile de microgrupuri. O componentă sesizată şi prelucrată de cercetători a fost umanismul antropocentric, individualizat de J. Maritain, curent care exaltă individul capabil de a-şi crea propria umanitate în conformitate cu propria lui plăcere, liber de orice constrângere. Pentru Lorenzo Chiarinelli secularizarea şi modernitatea nu sunt procese paralele şi nici totalmente omogene. În cultură rămân cel puţin trei elemente proprii secularizării: declinul principiului autorităţii şi înlocuirea lui cu cel al experienţei; laicitatea instituţiilor politice, economice şi culturale; stăpânirea unei culturi a bunăstării şi a timpului liber. Pentru spaţiul italian această ereditate s-a manifestat într-un relativism teoretic, în subiectivizarea credinţei şi a normelor morale, ecclesialitate condiţionată, care se transformă în apartenenţă parţială ; construirea unui sens difuz al sacrului care se traduce printr-un consumism religios ${ }^{9}$. Pe plan sociocultural şi în general în spaţiul public secularizarea este resimţită tot în trei moduri: banalizarea mesajului religios, suspiciunea faţă de religie, distanţarea totală a unora faţă de religie.

${ }^{9}$ Lorenzo CHIARINELLI, Al di là della secolarizzazione: sfida e chance per la chiesa cattolica, în La religione...II, p. 172. 
Dacă în general instituţiile religioase au suferit un declin, religiosul, ca fenomen, a renăscut într-o varietate de forme. În zorii celui de-al treilea mileniu experienţa colectivă a sacrului şi imaginaţia religioasă au căpătat forme inedite. Pentru Karl Marx, Emile Durkheim, Max Weber şi cea mai mare parte a sociologilor de la începutul secolului XX religia intrase într-un declin ireversibil.

De ce se impune o atenţie deosebită din partea teologilor privind fenomenul secularizării? Oare cercetătorul contemporan, preocupat de identificarea metodelor de echilibrare a faptului religios, va defini un ansamblu metodic teologic prin contrast cu paradigmele care fundamentează curentul secularist? În 2012 Jérôme Souty inventaria pentru centrul francez de cercetări umaniste metamorfozele prin care au trecut şi trec credinţele religioase, rezultate verificate statistic ${ }^{10}$. În primul rând se constată un proces de subiectivizare a credinţei, depărtare de ceea ce înseamnă credinţa tradiţională, în favoarea unei recompuneri a ceea ce Souty numeşte, sentimentul religios, un soi de sacru psihoemoţional din perspectiva noastră. Principalele caracteristici ale acestei recompuneri a sacrului, după anii 60 , sunt sintetizate în formula lui Françoise Champion ca nebuloas $\breve{a}$ mistico-ezoterică, sumarizând aici astrologia, reîncarnarea, telepatia, spiritismul, grupări sincretiste de origine orientală (neo-budismul, neohinduismul),New Age etc. În paralel cu această direcţie eclectică a religiosului ca fenomen psihoemoţional asistăm la dezvoltarea curentelor radicale în religiile istorice: reîntoarcerea la Torah pentru iudaism sau integrismul musulman etc.

\section{Reîntorcerea la istorie}

Filosofia precreştină este dominată de preocupări de a descoperi sensurile existenţei omului, a lumii, a divinităţilor. Din această perspectivă, se propun metodologii variate, pornindu-se fie 
de la modelele socratice (ştiu că nu ştiu - expresie învecinată cu smerenia creştină; maieutica socratică - arta moşitului ${ }^{11}$ ) concretizate în cele două aspecte ale vieţii: viaţa ca cercetare şi viaţa ca şi credinţă, fie de la ideile omnipotente ale lui Platon. Aristotel vede latura educabilă a omului justificată de existenţa raţiunii. Aceasta îl îndeamnă la depăşirea percepţiei instinctuale ca şi produs al afectelor şi îl provoacă pe om la dobândirea virtuţilor.

În creştinism, Mântuitorul Hristos este, prin excelenţă, Invăţătorul. Activitatea Sa este centrată pe chemarea omului la desăvârşire: „Fiţi desăvârşiţi precum şi Tatăl vostru cel din ceruri desăvârşit este" (Matei 5,48). Astfel, prezenţa şi rolul Mântuitorului Hristos în lume nu se reduce numai la a configura intelectual un anumit popor sau a defini o anumită arie geografică. Cuvântul Lui are valoare absolută, universală, fiind transmis oamenilor într-o pedagogie a desăvârşirii, a activismului, a libertăţii interioare, a egalităţii şi iubirii fraterne. De multe ori, Hristos îi prezintă pe copii drept model şi chip al desăvârşiriii ${ }^{12}$.

Principiile educaţionale ale creştinismului la nivel instituţional vor fi ilustrate exemplar în timpul Imperiului Bizantin. Deşi cronologia politică a vastului Bizanţ se sfầrşeşte în anul 1453, spiritualitatea şi cultura lui (modele culturale, educaţionale) au supravieţuit, realitate exprimată de Nicolae Iorga în sintagma Bizant după Bizanţ. În timpul primelor patru secole creştine asistăm la un proces de interogare şi adaptare culturală. Despre ce este vorba?

Aprecierea făcută de George Florovsky privind premisele unui raport original între cultura elenistă şi cea creştină surprinde, dincolo de ciocnirea acestora, o continuitate. Dar la ce nivel? „Cultura antică s-a dovedit destul de elastică pentru a accepta o transfigurare interioară... Creştinii au dovedit că a fost posibil să se redirecţioneze procesul cultural, fără a cădea într-o stare preculturală, să restructureze țesătura culturală într-un spirit nou. Acelaşi proces, descris în diverse chipuri ca elenizarea

${ }^{11}$ Constantin Cucoş, Educaţia religioasă. Repere teoretice și metodice, Ediția a IIa, Polirom, 2009, p. 76.

12 Ibidem, p. 82. Copilul are o capacitate specială de a fuziona cu obiectul, îl percepe instantaneu fără să apeleze la analiză, interogând funciar, intuitiv. 
creştinismului, poate fi conceput mai degrabă ca o încreştinare a elenismului"" ${ }^{3}$. Ca atare, se poate afirma faptul că educaţia bizantină continuă educaţia clasică.

Între primii Părinţi ai Bisericii care au încercat o sistematizare a unor posibile modele educaţionale creştine ${ }^{14}$ a fost Clement Alexandrinul. El este primul autor creştin care a lăsat o lucrare sistematică de pedagogie din care s-a inspirat mai târziu tradiţia creştină în ceea ce priveşte educaţia ${ }^{15}$. Din acelaşi spaţiu alexandrin face parte şi scriitorul bisericesc Origen. El a conceput programe de educaţie atât pentru elevii obişnuiţi, dar şi pentru cei care dovedeau calităţi excepţionale. A identificat trei niveluri semiotice în ceea ce priveşte interpretarea Bibliei: sensul literal, aplicarea morală pentru suflet şi sensul alegoric sau spiritual. Aceste sugestii se dovedesc deosebit de fecunde, mai ales când se pune problema realizării unei educaţii integrale nu numai pentru religie, dar şi prin intermediul religiei ${ }^{16}$. Din această perspectivă, finalitatea educaţiei se găseşte în dobândirea virtuţilor.

Pe parcursul istoriei creştinismului, această componentă se va dovedi centrală. Începând cu modelul educaţional propus de scriitorul bisericesc Lactanţiu, continuând cu creaţiile teologice şi literare ale Părinţilor bisericeşti (Sfântul Vasile cel Mare, Sfântul Ioan Gură de Aur, Sfântul Grigorie Teologul), peste tot se desprinde obligaţia tinerilor de a deprinde virtuţile, ca expresie a educaţiei integrale.

Lui Lactanţiu i-a încredinţat Constantin cel Mare educaţia fiului său Crispus, în ştiinţele clasice, dar şi în ceea ce priveşte formaţia creştină. La Trier, Lactanţiu a finalizat o lucrare foarte importantă pentru tradiţia creştină. Este vorba despre Instituţiile

13 George Florovsky, „Faith and Culture”, în St. Vladimir's Quaterly, 4, 1-2, 1955-1956, p. 40.

14 De mare importanţă sunt şcolile catehetice din Alexandria, Antiohia şi Edessa. În cadrul acestora s-a dezvoltat o primă teorie a învăţământului religios bazată pe Sfânta Scriptură şi pe Scrierile Părinţilor Apostolici.

15 Pentru modele educaţionale diacronice este utilă lucrarea: Dorin OpRIŞ, Dimensiuni creştine ale pedagogiei moderne, Iaşi, Editura Sf. Mina, 2010.

${ }^{16}$ Robert BrownIng, „Byzantine Scholarship”, în Past \& Present, nr28, 1964, p. 3-4. 
Educația teologică între expresia duhovnicească și constrângerile seculare ale contemporaneității

divine (Divinae Institutiones), carte care se dorea a fi un model de urmat în educaţia creştină. La începutul lucrării, Lactanţiu face o rugăciune de invocare a adevăratului Dumnezeu, care a creat toate lucrurile. Divinitatea creştină prezentată de Lactanţiu este Gândirea veşnică şi echilibrul universului, aşa cum comandantul de arme este echilibrul unei întregi oştiri pe câmpul de luptă.

Instituţiile sunt alcătuite sub forma a două planuri antitetice. Antiteza constă din punerea în contrast a adevăratei învăţături creştine cu falsa învăţătură păgână. Primele trei capitole prezintă o sinteză a greşelilor (Despre falsa religie; Originea greşelii; Despre falsa inţelepciune), iar următoarele trei oglindesc adevărata înţelepciune (Despre adevărata înţelepciune şi adevărata religie; Despre dreptate; Despre adevăratul cult). Finalul este o invocare apocaliptică numită Despre viaţa fericită ${ }^{17}$. Cartea a VI-a conţine la sfârşitul capitolului 26 o inserţie alcătuită în stilul lui Laus Constantini, un paragraf care nu se găseşte în totalitatea manuscriselor, dar a cărui autenticitate a fost demonstrată. Fără a avea entuziasmul lui Eusebiu, explicabil de altfel prin anul scrierii (313) şi prin faptul că împăratul acum începea să crească în convingerea creştină, Lactanţiu face un elogiu care se diferenţiază net de Panegiricul păgân: „Dar toate plăsmuirile au aţipit de acum, prea venerate împărat, de când supremul Dumnezeu te-a chemat pentru a restabili lăcaşul dreptăţii spre protejarea neamului omenesc. De când eşti tu cel care conduci destinul statului roman, noi, cinstitorii lui Dumnezeu, nu mai suntem luaţi drept blestemaţi şi nelegiuiţi, de când adevărul iese la iveală..."18.

17 Lactantius, Divinae Institutiones, VII, 11-17, trad. rom. Instituţiile Divine, traducere şi note de Petru PISTOL, Timişoara, Editura Învierea, 2004; Vincenzo LoI, Per la storia del vocabolo „, sacramentum,, : ,sacramentum,, in Lattanzio, în Vigiliae Christianae, vol. 18, 2/1964, p. 85-107; Arthur L. FISHER, „Lactantius' Ideas Relating Christian Truth and Christian Society”, în Journal of the History of Ideas, vol. 43, 3/1982, p. 355-377; Christopher OCKER, Unius Arbitrio Mundum Regi Necesse Est: Lactantius' Concern for the Preservation of Roman Society, în Vigiliae Christianae, vol. 40, 4/1986, p. 348-364.

${ }^{18}$ Lactantius, Divinae Institutiones, VI, p. 342. 
Supremul Dumnezeu este o expresie personalizată care face referire directă la cea mai puternică divinitate care se ridică deasupra politeismului antic. Astfel se naşte paralelismul dintre monarhia divină şi monarhia imperială romană. Chemat - nu hazardul a făcut posibil urcarea la tron a lui Constantin, ci chemarea care are la bază alegerea unei persoane conform planului veşnic, proniator, al lui Dumnezeu. Mai presus prin virtute şi prosperitate - împăratul are obligaţia de a lucra virtutea. Mâna dreaptă a lui Dumnezeu, puternică, te-a apărat de toate primejdiile - este o apropiere specială între Dumnezeu şi împărat. Lactanţiu face aici o trimitere la civilizaţia ebraică în care regele devenea unsul lui Dumnezeu, de unde avea o seamă de prerogative.

Virtuţile împăratului sunt daruri de la Dumnezeu. Astfel

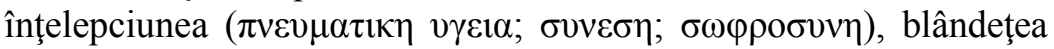

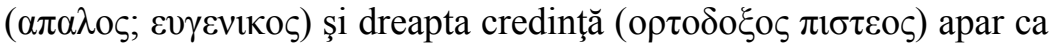
virtuţi cardinale care-1 legitimează pe împărat la o recunoaştere universală ca împărat al împăraţilor şi domn al domnilor.

Ceea ce asigură permanența în veşnicie a împăratului este smerenia care urmează cunoaşterii lui Dumnezeu. În fapt, aceste două stări sunt simultane, fără a putea susține un raport de anterioritate sau posterioritate de tipul cunoaşterea lui Dumnezeu este un fapt apriori smereniei, deoarece smerenia este cunoaştere a lui Dumnezeu. Cunoaşterea lui Dumnezeu nu este una de tip gnostic, ci izvor a toată virtutea: tuturor făcător de bine, de biruinţă dătător, mai înalt decât toată stăpânia. Chemarea la o stăpânire universală (tema oikoumene) revine frecvent prin folosirea adjectivului tot, toată, toţi, toate $(\pi \alpha \varsigma$, $\pi \alpha \sigma \alpha, \pi \alpha v)$. Împărăţia este universală deoarece Îndreptătorul ei, Proniatorul, nu este un om simplu, ci Mântuitorul lisus Hristos.

Traducerea din limba greacă a termenului de credincios vine să nuanţeze sensurile în care apare Constantin în conştiinţa Bisericii.

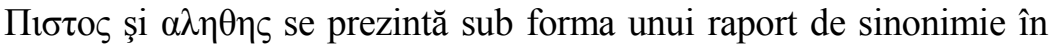
care credincios este identic cu adevărat. Atunci omul fiinţează cu adevărat, când este credincios. Astfel, expresia sunt credincios este identică cu sunt în adevăr sau sunt adevărat. Din acest punct de vedere se realizează o trilogie obligatorie om-credincios-adevăr, care are ca finalitate sfântul - ca expresie a Adevărului. 


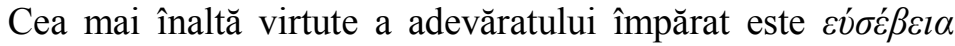
(evlavie, pietate, smerenie, credinţă sau sinteză a tuturor virtuţilor creștine), un termen cu semnificaţii foarte largi. În cadrul unei explicaţii mai extinse pornind de la conceptul de $\varepsilon v ́ \sigma \varepsilon ́ \beta \varepsilon \imath \alpha$, distingem două subcomponente care se condiţionează reciproc. Prima componentă este cunoaşterea de Dumnezeu, condiţionată de credinţă, văzută ca rationabile obsequium. A doua componentă este aplicaţia în viaţa cotidiană a acestei credinţe, a virtuţii care trebuie întrupată. În această $\varepsilon v ́ \sigma \varepsilon ́ \beta \varepsilon \imath \alpha$ stă de fapt quintesenţa creştinismului. Dar $\varepsilon v ́ \sigma \varepsilon ́ \beta \varepsilon \imath \alpha$ este o virtute sau o stare specifică împăratului. Prin ea împăratul devine rob, slugă a lui Dumnezeu. Datorită acestei virtuţi, împăratul a primit în sine sămânţa dumnezeiască şi tot datorită ei primeşte în sine imaginea lui Dumnezeu ca Împărat Veşnic. Dumnezeu 1-a pus să fie un exemplu pentru toţi, maestru îndrumător pentru alţii, el fiind $\varepsilon \dot{v} \sigma \varepsilon \dot{\beta} \dot{\eta} \beta \alpha \sigma l \lambda \varepsilon v ́ \varsigma$, luminând tot pământul cu a sa $\varepsilon v ́ \sigma \varepsilon ́ \beta \varepsilon \varepsilon \imath$.

Virtuţile cu referire la supuşi sunt următoarele: bunătatea

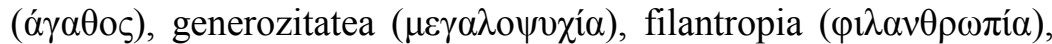
grija apropiată faţă de problemele supuşilor manifestată prin $\pi \rho o ́ v o 1 \alpha$, compasiune ( $\sigma 0 \mu \pi \alpha \theta \varepsilon \ddot{v} v)$, milostenia ( $\varepsilon \lambda \varepsilon \circ \varsigma ; \alpha \xi 10 \lambda v \pi \eta \tau o \varsigma)$,

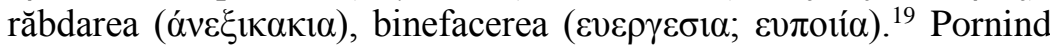
de la această adevărată structură a obiectivelor unei educaţii creştine a împăratului, Thomas Magistrul, vieţuitor în secolul al XIV-lea, în timpul războiului civil dintre Andronic al II-lea şi Andronic al III-lea (1321-1328), după ce reafirmă faptul că modelul de educaţie creştină trebuie să se adreseze deopotrivă împăratului şi supuşilor, propunând reorganizarea educaţiei în oraşele imperiului, recomandă alegerea unor profesori responsabili care să-i ajute pe tineri să-şi depăşească patimile pentru a se bucura de virtute. El condiţionează atingerea acestui scop şi de rolul părinţilor ${ }^{20}$.

19 Glanville DownEy, „Education in the Christian Roman Empire: Christian and Pagan Theories under Constantine and His Successors", în Speculum, vol. 32, 1/1957, p. 49-56.

${ }^{20}$ Franz TinNEFELD, „Intellectuals in Late Byzantine Thessalonike”, în Dumbarton Oaks Papers, vol. 57, Symposium on Late Byzantine Thessalonike, 2003, p. 166. 


\section{Sarcini teologice}

Societatea modernă guvernată masiv de tipologia raţiunii instrumentală, şi-a construit propria autonomie sustrăgându-se de la referinţele simbolice caracteristice credinţei, care ofereau societăţii interpretări eteronome ale lumii şi ale omului. Dominată de ceea ce Marcel Gauchet numea imperativul schimbării, modernitatea ca şi contemporaneitatea, trăiesc într-o condiţie structurală de nesiguranţă, de incertitudine. Dacă se porneşte de la prezumpţia că secularizarea se impune modernităţii ca un proces ineluctabil de reducere raţională a credinţei, rezultă că societatea este una secularizată ${ }^{21}$, negând sursa de optimism a credinţei.

Cum poate credinţa creştină să îşi facă simţită prezenţa în această societate: valorizând comunitatea parohială; situându-se la nivelul legitimărilor ultime; prin formare duhovnicească continuă; vocaţie a integralităţii şi denunţare a parţialităţii; identitate culturală dinamică; dar nu în ultimul rând participarea la universul sacramental, la rugăciune şi slujire. Secularizarea obligă religia la o seamă de atitudini dintre care cele mai urgente ar fi:

a. transfigurare (rugăciune, smerenie, împărtăşirea cu Hristos Domnul) şi divino-umanitate. Din perspectiva unei eshatologii active se impune realizarea unui efort de a lumina cultura şi societatea prin viaţă liturgică şi spirituală, printr-o continuă formare duhovnicească. Pe parcursul istoriei au fost momente când creştinătatea construia paradigme despre un Dumnezeu contrar omului, antiuman. Ori modernitatea a construit omul împotriva lui Dumnezeu. În fapt inima teologiei creştine este realitatea îndumnezeirii, în baza sintezei divino-umane a Întrupării. Omenirea are acest mandat de a descoperi raţiunile divine ale existenţei care se acordă cu semnificaţia ultimă, cu Logosul. Creştinismul nu se epuizează în modele culturale sau sociologice, ci îndreaptă perspectiva către dincolo.

${ }^{21}$ Daniele Hervieu LEGER, Credere nell ambito della modernita:aspetti del fatto religioso, în La religione I..., p. 551. 
b. derularea proceselor de cercetare în domeniul teologiei cu precădere în latura intelectivă, ce ţine de predarea religiei în şcoală $^{22}$. Identificarea principalelor nevoi de intervenţie adaptată în rândulelevilor şi studenţilor. Din acest punct programele pot fi nucleul dezvoltărilor proiectelor catehetice la alte categorii de vârstă sau în funcţie de profilul general al persoanelor în strânsă legătură cu structura parohială.

c. pre-comprehensiunea mesajului, posibilitatea de a-l face inteligibil contemporaneităţii. Societatea secularizată se caracterizează prin tăcere asupra lui Dumnezeu, ori sarcina teologiei este aceea de a se integra unei viziuni omogene despre om şi despre lume. Tăcerea asupra lui Dumnezeu devine încet un aspect al „teologiei negative: iese la lumină un cuvânt care ţine de pudoare însă refuză tăcerea, care ţine de durere, dar care îi permite luminii să treacă prin ea. Departe de orice raţionament scolastic, un cuvânt al puterii umile, un cuvânt al bucuriei şi al libertăţii. Strigătul lui Dimitri Karamazov: Dacă îl alungăm pe Dumnezeu de pe pământ, îl vom întâlni sub pământ; atunci noi, oamenii de sub pământ vom cânta cu măruntaiele pământului un imn tragic pentru Dumnezeul bucuriei. Trăiască Dumnezeu şi bucuria sa, îl iubesc ${ }^{23}$.

d. definirea conţinuturilor educaţiei religioase şi identificarea metodelor de pedagogie şi andragogie în vederea precomprehensiunii mesajului; conceperea instrumentelor de lucru. Eforturile sunt multiple în ultima vreme, mai ales în urma contestării statutului orei de religie din partea grupurilor seculariste. In acest sens Patriarhia Română a încurajat depunerea şi derularea de proiecte care au ca şi obiectiv identificarea metodelor de lucru noi, adaptate nevoilor pastorale. Au fost înfiinţate Centre de Resurse în mai multe eparhii din ţară, în acest sens în plan local fiind ilustrativ Centrul de Training

22 Institutul de Ştiinţe ale Educaţiei din România a dezvoltat o preocupare specială în ceea ce priveşte pedagogia Religiei, ca disciplină predată în şcoală, rezultatele cercetării constituind premisele construirii pe baze reale a unei strategii pe termen mediu şi lung privind locul şi funcţia Religiei în şcoală (Constantin Cucoş, Dorin Opriş, Monica Opriş, Muşata Bocoş, Irina Horga, Vasile Creţu etc.).

${ }^{23}$ Olivier Clement, op. cit., p. 48. 
Dynamis al Arhiepiscopiei de Alba Iulia, centru specializat pe metode şi tehnici de educaţie nonformală ${ }^{24}$.

„Într-o societate modernă, secularizată, Biserica, sau mai degrabă Bisericile, sunt nevoite să-şi găsească locul. Nu un loc dominant. $\mathrm{Nu}$ un loc marginal, un ghetou al frici şi al orgoliului departe de cultură şi de viaţa comunitară. Biserica, bisericile trebuie să se situeze, fără frică sau orgoliu, într-un anume fel faţă către faţă cu această societate, cu certitudinea că aceasta are nevoie de credincioşi pentru a exista, fiindcă Biserica este inima lumii, chiar dacă lumea îşi ignoră inima, ca să-l cităm pe mitropolitul Georges Khodr! Este exact situaţia pe care o revendicau apologeţii secolelor II şi III faţă de Imperiul roman. Acest parteneriat polemic va fi când conflictual, cu riscul martiriului, când plin de inspiraţie. Reprezintă în el însuşi un aspect de explorat al divino-umanităţii. Anunţă un divino-umanism încă de negândit pentru noi, acest aliaj, creuzet de Ev mediu, de Renaştere, al unei libertăţi eliberate la care au visat un Nicolai Berdiaev, un Maurice Clavel? Nu ştiu. Ştiu numai că, în secolul XX, creştinismul şi mai cu seamă poate, Biserica Ortodoxă deţine un număr imens de martiri -fără să uităm, atât în apropierea Muntelui Athos, martiriul alb al călugărilor- şi că aici există un miez de energie capabil, dacă nu se îndepărtează de inteligenţa contemporană, ci o însămânţează, să răstoarne istoria" ${ }^{25}$.

$\cos 80$

\section{Bibliografie}

1. La Bible, traduction ocuménique TOB, Société Biblique Française, Les Éditions du Cerf, 1994.

2. Septuaginta, edit. Alfred Rahlfs, Stuttgart, Deutsche Bibelgesellschaft, 1979.

24 Centrul de Training Dynamis este specializat pe programe de dezvoltare personală, facilitând procese de explorare personală, conştientizarea şi acceptarea sinelui în vederea transformării, dezvoltării fizice, psihice, emoţionale şi spirituale, furnizează programe de formare iniţială şi continuă în metode şi tehnici nonformale de educaţie, din perspectivă creştin-ortodoxă.

${ }^{25}$ Olivier CLEMENT, op. cit., p. 52. 
Educația teologică între expresia duhovnicească și constrângerile seculare ale contemporaneității

3. Die Heissen Eisen von A bis Z, Johannes Bauer, Verlag, Graz, Austria, trad. it. Dizionario Teologico, Roma, Cittadela Editrice, 1974, $741 \mathrm{p}$.

4. Dizionario Enciclopedico di Teologia Morale, diretto da Leandro Rossi e Ambrogio Valsechi, Roma, Ed. Paoline, 1974, 1274 p.

5. BROWNING, Robert, Byzantine Scholarship, în „Past \& Present”, 28/1964, p. 3-20.

6. Buchthal, Hugo, Studies in Byzantine Illumination of the Thirteenth Century, în „Jahrbuch der Berliner Museen”, bd. 25 , 1983, p. 27-102.

7. Cavallo, Gugliemo (coord.), Omul bizantin, Iași, Polirom, 2000.

8. Clement Olivier, La révolte de l'Esprit, Paris, Stock, 1979, 439 p.

9. Clement Olivier, Viaţa din inima morţii, Târgovişte, Pandora, 2001, 253 p.

10. CoDOBAN Aurel, Sacru şi ontofanie-pentru o nouă filosifie a religiilor, Iaşi, Polirom, 1998, 185 p.

11. CuCoş, Constantin, Educaţia religioasă. Repere teoretice şi metodice, Ediția a II-a, Iaşi, Polirom, 2009.

12. DANCĂ Wilhelm, Mircea Eliade- Definitio sacri, Iaşi, Ars Longa, 1998, $365 \mathrm{p}$.

13. DJuvarA, Neagu, Civilizaţii şi tipare istorice - un studiu comparat al civilizaţiilor, Bucureşti, Humanitas, 2004.

14. DowneY, Glanville, Education in the Christian Roman Empire: Christian and Pagan Theories under Constantine and His Successors, în „Speculum”, vol. 32, 1/1957, p. 48-61.

15. DRIMBA, Ovidiu, Istoria culturii şi civilizaţiei, vol. IV, București, Editura Saeculum I.O., 1998.

16. FLOROVSKY, George, Faith and Culture, în „St. Vladimir's Quaterly", 4, 1-2, 1955-1956.

17. GEORGESCU, Maria, Incursiune în cultura bizantină, Târgovişte, Editura Cetatea de Scaun, 2004.

18. HARDY, Carmon, The Emperor Julian and His School Law, în „Church History”, vol. 37, 2/1968, p. 131-143.

19. IORGA, Nicolae, Histoire de le vie byzantine, Bucureşti, Editura Chausee, 1934.

20. MARou, Henri-Irénée, Histoire de l'éducation dans l' Antiquité, Éditions du Seuil, Paris, 1948 et 1981, trad. rom. Istoria educaţiei în antichitate, vol. II, Bucureşti, Editura Meridiane, 1997.

21. OPRIŞ, Dorin (coord.), Coordonate ale cercetării pedagogice în domeniul educatiei religioase, Alba Iulia, Editura Reîntregirea, 2009. 
Ovidiu

22. OPRIŞ, Dorin, Dimensiuni creştine ale pedagogiei moderne, Ediţia a II-a, Iaşi, Editura Sf. Mina, 2010.

23. TINNEFELD, Franz, Intellectuals in Late Byzantine Thessalonike, în „Dumbarton Oaks Papers”, vol. 57, Symposium on Late Byzantine Thessalonike, 2003, p. 153-172.

24. TREADGOLD, Warren, $O$ istorie a statului şi societăţii bizantine, Iaşi, Institutul European, 2004.

25. TREADGOLD, Warren, The Revival of Byzantine Learning and the Revival of the Byzantine State, in ,The American Historical Review", vol. 84, 5/1979, p. 1245-1266. 